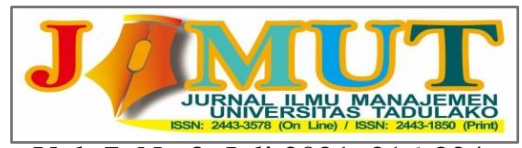

Vol. 7, No 3, Juli 2021, 216-224

\title{
PENGARUH ATRIBUT PRODUK TERHADAP KEPUTUSAN PEMBELIAN BAN SEPEDA MOTOR MEREK FDR DI KOTA PALU
}

\author{
Tahyudin \\ Ira Nuriya Santi \\ Program Studi S1, Jurusan Manajemen, Fakultas Ekonomi dan Bisnis, Universitas Tadulako \\ Email: tahyudinyudhi089@gmail.com
}

\begin{abstract}
This study aims to determine the effect of product attributes consisting of brand, product quality, price and design on the purchase decision of FDR brand motorcycle tires in Palu City. The sample in this study amounted to 60 respondents. The sampling technique uses incidental sampling. Data collection techniques using a questionnaire. The method of data analysis uses Multiple Linear Regression. The results showed that the product attribute variables consisting of brand, product quality, price and design simultaneously had a significant effect on purchasing decisions for FDR brand motorcycle tires in Palu City. Furthermore, brand variables, product quality, price and design partially have a significant effect on purchasing decisions for FDR motorcycle tires in the city of Palu.
\end{abstract}

Keywords: Product Attributes, Purchasing Decisions.

\begin{abstract}
ABSTRAK
Penelitian ini bertujuan untuk mengetahui pengaruh atribut produk yang terdiri dari merek, kualitas produk, harga dan desain terhadap keputusan pembelian ban sepeda motor merek FDR di Kota Palu. Sampel dalam penelitian ini berjumlah 60 responden. Teknik pengambilan sampel menggunakan sampling insidental. Teknik pengumpulan data menggunakan kuesioner. Metode analisis data menggunakan Regresi Linear Berganda. Hasil penelitian menunjukkan bahwa variabel atribut produk yang terdiri dari merek, kualitas produk, harga dan desain secara simultan berpengaruh signifikan terhadap keputusan pembelian ban sepeda motor merek FDR di Kota Palu. Selanjutnya variabel merek, kualitas produk, harga dan desain secara parsial berpengaruh signifikan terhadap keputusan pembelian ban sepeda motor merek FDR di Kota Palu.
\end{abstract}

Kata Kunci: Atribut Produk, Keputusan Pembelian.

\section{PENDAHULUAN}

Pemasaran dalam industri otomotif saat ini berkembang sangat pesat, khususnya sepeda motor. Perkembangan tersebut berdampak langsung terhadap pertumbuhan industri pendukungnya. Meningkatnya kebutuhan spare part (suku cadang/alat-alat sepeda motor). Salah satu spare part (suku cadang) yang sering diganti khususnya sepeda motor adalah ban. Jumlah sepeda motor yang terus bertambah dari tahun ketahun tentu kebutuhan ban pun akan meningkat. Saat ini, semakin banyak bermunculan berbagai jenis merek ban sepeda motor yang dipasarkan di Indonesia khususnya Kota Palu. Salah satunya ban merek FDR. Hal ini tentu menyebabkan terjadinya persaingan yang sangat ketat. Ban merek FDR bersaing dengan ban merek lain dari dalam negeri maupun luar negeri, seperti merek IRC, Corsa, Mizzle, Swallow, Dunlop, Michelin dan lain-lain. Maka dari itu produsen merek FDR harus menciptakan produk ban sepeda motor yang dapat memuaskan konsumennya. Hal ini agar ban merek FDR dapat bertahan dalam industri penjualan ban sepeda motor. 


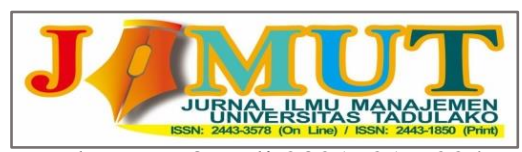

Vol. 7, No 3, Juli 2021, 216-224

Konsumen dalam membeli suatu produk dipengaruhi oleh berbagai faktor salah satunya atribut produk itu sendiri. Atribut produk yang menarik akan berdampak pada keputusan pembelian produk. Menurut Tjiptono (2008:103) atribut produk ialah unsur-unsur produk yang dipandang penting oleh konsumen serta dijadikan dasar pengambilan keputusan pembelian. Kotler dan Keller (2009:237) menjelaskan atribut yang diminati oleh pembeli berbeda-beda bergantung jenis produknya misalnya ban yaitu keselamatan, umur pemakaian, mutu ketika dikendarai dan harga. Peter dan Olson (2014:189), mengemukakan atribut produk meliputi merek, kualitas produk, harga dan desain. Pengguna sepeda motor di Kota Palu memiliki kelas sosial yang berbeda. Keputusan pembelian ban sepeda motor konsumen mempertimbangkan berbagai aspek termasuk merek, kualitas, harga dan desain yang sesuai dengan persepsi dan selera mereka masing-masing.

Merek merupakan atribut produk yang penting. Merek untuk membedakan satu produk dengan produk yang lain. Produsen harus memperkuat merek dibenak konsumen yaitu dengan mempromosikan ban merek FDR sehingga pembelian konsumen akan terus meningkat. Atribut selanjutnya yaitu kualitas produk merupakan salah satu atribut yang harus diperhatikan oleh setiap perusahaan jika ingin produk yang dihasilkan dapat bersaing dengan ban merek lain. Konsumen semakin kritis dalam menggunakan suatu produk dan selalu ingin mendapatkan produk yang berkualitas. Selanjutnya harga merupakan salah satu yang menjadi pertimbangan konsumen dalam menentukan keputusan pembelian. Produsen ban merek FDR harus jeli dalam menetapkan harga produknya. Produk dengan harga yang sesuai persepsi konsumen akan diminati. Desain merupakan salah satu atribut produk yang penting. Produk dengan desain yang menarik akan diminati oleh konsumen.

\section{KAJIAN LITERATURE DAN PENGEMBANGAN HIPOTESIS}

\section{Pengertian Pemasaran}

Kotler dan Amstrong (2008:6), mengemukakan "pemasaran (marketing) ialah proses sosial dan manajerial yang mengakibatkan individu maupun kelompok mendapatkan apa yang mereka butuhkan dan inginkan lewat pencitraan serta pertukaran produk dan nilai dengan pihak lain”. Definisi lain dari pemasaran menurut America Marketing Association (AMA) yang dikutip dalam Kotler dan Keller (2009:5), mengemukakan "pemasaran ialah suatu fungsi organisasi dan serangkaian proses untuk menciptakan, mengomunikasikan, serta memberikan nilai kepada pelanggan dan untuk mengelola hubungan pelanggan dengan cara yang menguntungkan organisasi serta pemangku kepentingannya". Menurut Tjiptono (2008:7), pemasaran merupakan suatu proses sosial dan manajerial dimana individu atau kelompok mendapatkan apa yang mereka butuhkan dan inginkan melalui penciptaan, pewarnaan, serta pertukaran segala sesuatu yang bernilai dengan orang ataupun kelompok lain.

\section{Atribut Produk}

Kotler dan Amstrong (2008:272), mengemukakan bahwa pengembangan suatu produk maupun jasa melibatkan pendefinisian manfaat yang ditawarkan produk atau jasa tersebut. Manfaat ini dikomunikasikan serta dihantarkan oleh atribut produk seperti kualitas, fitur, serta gaya dan desain. Menurut Tjiptono (2008:103), atribut produk ialah unsur-unsur produk yang dipandang penting oleh konsumen serta dijadikan dasar pengambilan keputusan pembelian. Atribut produk meliputi merek, kemasan, jaminan, pelayanan dan sebagainya. Menurut Peter dan Olson (2014:189), produk dan atribut produk ialah stimulus utama yang memengaruhi afeksi, kognisi, dan perilaku konsumen, pemasaran dan informasi lain juga memengaruhi pembelian dan penggunaan produk akan memuaskan atau tidak. Peter dan Olson juga mengemukakan atribut produk meliputi merek, kualitas produk, harga dan desain. 


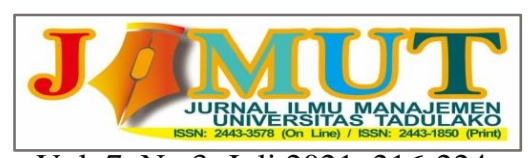

Vol. 7, No 3, Juli 2021, 216-224

\section{Keputusan Pembelian}

Tjiptono (2008:21), mengemukakan: "keputusan pembelian konsumen ialah tindakan individu yang secara langsung maupun tidak langsung terlibat dalam usaha memperoleh serta menggunakan suatu produk atau jasa yang dibutuhkan”. Kotler dan Keller (2009:235), mengemukakan pengambilan keputusan ialah suatu tindakan individu yang secara langsung berperan dalam memperoleh serta menggunakan barang yang ditawarkan. Tahap-tahap dalam proses pengambilan keputusan sebagai berikut:

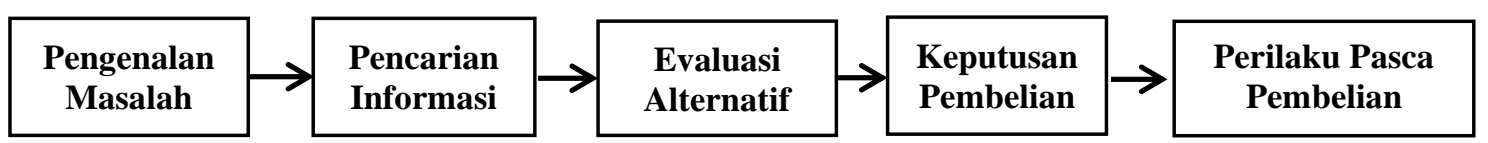

Sumber: Kotler dan Keller (2009:235)

Gambar 1. Keputusan Pembelian

\section{Kerangka Pemikiran}

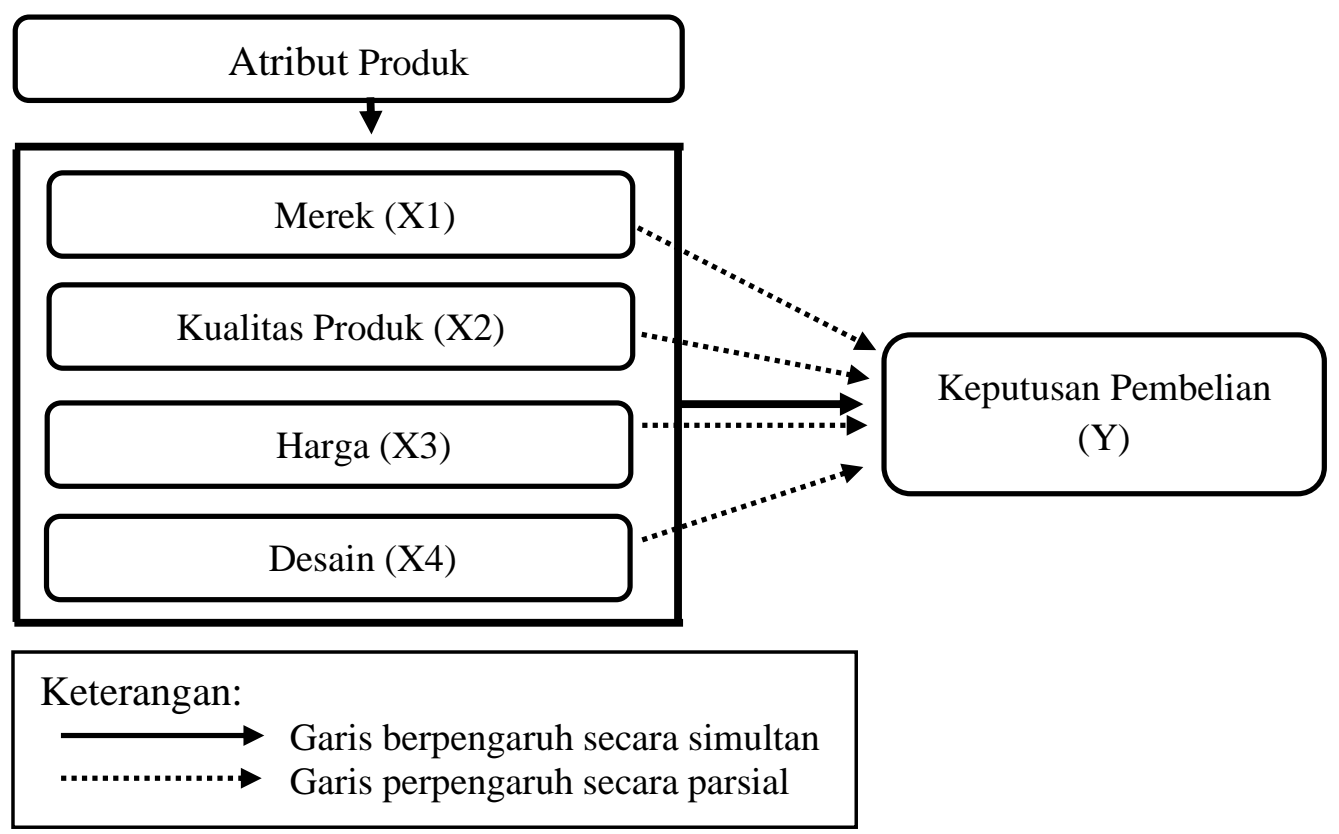

Gambar 2. Kerangka Pemikiran

\section{Hipotesis}

Berdasarkan kerangka pemikiran di atas maka peneliti merumuskan hipotesis penelitian sebagai berikut:

1. Atribut produk yang terdiri dari merek, kualitas produk, harga dan desain secara simultan berpengaruh signifikan terhadap keputusan pembelian ban sepeda motor merek FDR di Kota Palu.

2. Merek secara parsial berpengaruh signifikan terhadap keputusan pembelian ban Sepeda motor merek FDR di Kota Palu.

3. Kualitas produk secara parsial berpengaruh signifikan terhadap keputusan pembelian ban Sepeda motor merek FDR di Kota Palu.

4. Harga secara parsial berpengaruh signifikan terhadap keputusan pembelian ban Sepeda motor merek FDR di Kota Palu.

5. Desain secara parsial berpengaruh signifikan terhadap keputusan pembelian ban sepeda motor merek FDR di Kota Palu. 


\section{METODE PENELITIAN}

\section{Jenis Penelitian}

Penelitian ini merupakan jenis penelitian deskriptif kausal. Menurut Sugiyono (2014:147), metode deskriptif ialah metode yang digunakan untuk mendeskripsikan maupun menggambarkan data yang terkumpul sebagaimana adanya tanpa bermaksud membuat kesimpulan yang berlaku untuk umum. Penelitian kausal digunakan untuk menyelidiki kemungkinan hubungan sebab akibat dengan cara berdasarkan atas pengamatan terhadap akibat yang ada mencari kembali faktor yang mungkin menjadi penyebab melalui data tertentu. Suryabrata (2014:84).

\section{Objek Penelitian}

Objek dari penelitian ini ialah variabel pengaruh atribut produk terhadap keputusan pembelian ban sepeda motor merek FDR di Kota Palu, dimana variabel atribut produk (merek, kualitas produk, harga serta desain) ini merupakan variabel yang memengaruhi keputusan pembelian ban sepeda motor merek FDR di Kota Palu.

\section{Populasi}

Populasi dari penelitian ini yaitu pengguna sepeda motor yang menggunakan ban merek FDR di Kota Palu. Jumlah populasi dalam penelitian ini tidak diketahui secara pasti karena tidak memiliki data yang pasti mengenai jumlah pengguna sepeda motor yang menggunakan ban merek FDR di Kota Palu.

\section{Sampel}

Mengingat jumlah populasi dalam penelitian ini tidak diketahui, maka besarnya sampel ditentukan merujuk pada teori Roscoe dalam Sugiyono (2014:129), menyatakan bahwa bila dalam penelitian akan melakukan analisis dengan multivariate (korelasi atau regresi ganda), maka jumlah sampel minimal 10 kali jumlah variabel yang diteliti (independen+dependen). Jumlah variabel dalam penelitian ini adalah 5 yang terdiri dari variabel independen (merek, kualitas produk, harga dan desain) serta variabel dependen (keputusan pembelian). Berdasarkan pertimbangan tersebut maka jumlah sampel sebesar $12 \times 5=60$.

\section{Teknik Penarikan Sampel}

Teknik penarikan sampel yang digunakan dalam penelitian ini sampling insidental, dalam metode ini, pengambilan sampel berdasarkan kebetulan, yaitu siapa saja yang secara kebetulan atau insidental bertemu dengan peneliti dapat dijadikan sebagai sampel, apabila dipandang orang yang kebetulan ditemui itu cocok sebagai sumber data.

\section{Teknik Pengumpulan Data}

Teknik pengumpulan data yang digunakan dalam penelitian ini yaitu observasi, wawancara dan kuesioner.

\section{Regresi Linear Berganda}

Penelitian ini menggunakan perhitungan statistik analisis Regresi Linear Berganda dengan bantuan program SPSS 22.0. Variabel bebas dalam penelitian ini yaitu atribut produk (X) yang terdiri dari merek (X1), kualitas produk (X2), harga (X2) dan desain (X4) terhadap variabel terikatnya yaitu keputusan pembelian (Y). Persamaan Regresi Linear Berganda dalam penelitian ini adalah:

$$
\hat{Y}=a+b_{1} X_{1}+b_{2} X_{2}+b_{3} X_{3}+b_{4} X_{4}
$$


Dimana:

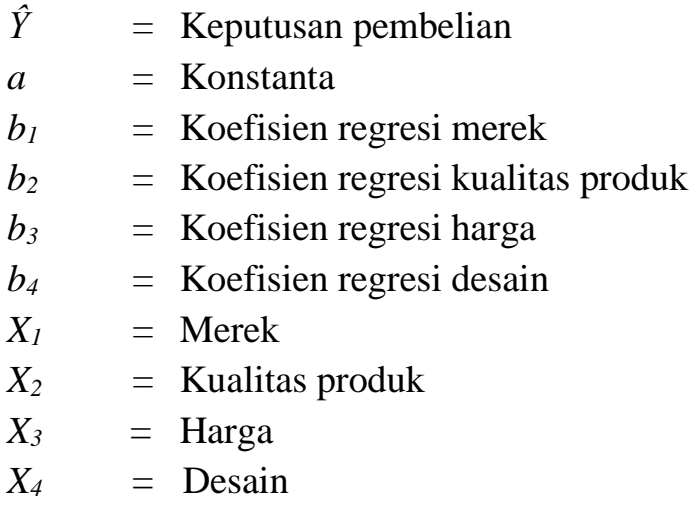

\section{HASIL DAN PEMBAHASAN}

\section{Hasil Uji Validitas}

Hasil uji validitas yang diperoleh dari setiap item pernyataan dapat dilihat pada Tabel berikut ini: Tabel 1. Hasil Uji Validitas

\begin{tabular}{|c|c|c|c|c|c|}
\hline No & $\begin{array}{c}\text { Variabel } \\
\text { Penelitian }\end{array}$ & $\begin{array}{c}\text { Item } \\
\text { Pernyataan }\end{array}$ & r hitung & $r$ tabel & Keterangan \\
\hline \multirow{12}{*}{1} & \multirow{3}{*}{$\begin{array}{c}\text { Merek } \\
\text { (X1) }\end{array}$} & $\mathrm{X} 1.1$ & 0,492 & 0,3 & Valid \\
\hline & & X1.2 & 0,673 & 0,3 & Valid \\
\hline & & $\mathrm{X} 1.3$ & 0,601 & 0,3 & Valid \\
\hline & \multirow{3}{*}{$\begin{array}{l}\text { Kualitas Produk } \\
\text { (X2) }\end{array}$} & $\mathrm{X} 2.1$ & 0,514 & 0,3 & Valid \\
\hline & & $\mathrm{X} 2.2$ & 0,558 & 0,3 & Valid \\
\hline & & $\mathrm{X} 2.3$ & 0,652 & 0,3 & Valid \\
\hline & \multirow{3}{*}{$\begin{array}{l}\text { Harga } \\
\text { (X3) }\end{array}$} & X3.1 & 0,629 & 0,3 & Valid \\
\hline & & X3.2 & 0,634 & 0,3 & Valid \\
\hline & & X3.3 & 0,542 & 0,3 & Valid \\
\hline & \multirow{3}{*}{$\begin{array}{l}\text { Desain } \\
\text { (X4) }\end{array}$} & $\mathrm{X} 4.1$ & 0,629 & 0,3 & Valid \\
\hline & & $\mathrm{X} 4.2$ & 0,716 & 0,3 & Valid \\
\hline & & $\mathrm{X} 4.3$ & 0,518 & 0,3 & Valid \\
\hline \multirow{5}{*}{2} & \multirow{5}{*}{$\begin{array}{c}\text { Keputusan } \\
\text { Pembelian } \\
\text { (Y) }\end{array}$} & Y1 & 0,576 & 0,3 & Valid \\
\hline & & $\mathrm{Y} 2$ & 0,652 & 0,3 & Valid \\
\hline & & $\mathrm{Y} 3$ & 0,576 & 0,3 & Valid \\
\hline & & Y4 & 0,592 & 0,3 & Valid \\
\hline & & Y5 & 0,607 & 0,3 & Valid \\
\hline
\end{tabular}

Sumber: Data Primer (diolah kembali 2019)

Berdasarkan Tabel $1 \mathrm{di}$ atas, terlihat bahwa setiap indikator yang digunakan untuk mengukur variabel-variabel yang ada adalah valid atau layak digunakan. Hal ini didasarkan melalui perbandingan antara nilai $r$ hitung yang lebih besar dari $r$ tabel yaitu 0,3 .

\section{Hasil Uji Reliabilitas}

Hasil pengujian reliabilitas untuk masing-masing variabel dapat dilihat pada Tabel sebagai berikut:

Tabel 2. Hasil Uji Reliabilitas

\begin{tabular}{|l|l|c|c|c|}
\hline No. & Variabel Penelitian & $\begin{array}{c}\text { Cronbach } \\
\text { Alpha }\end{array}$ & $\begin{array}{c}\text { Alpha } \\
\text { Tolerance }\end{array}$ & Ket. \\
\hline
\end{tabular}




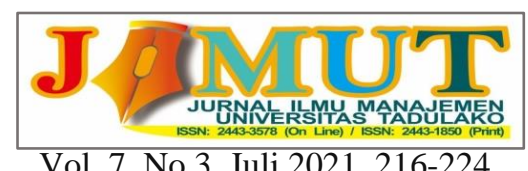

Vol. 7, No 3, Juli 2021, 216-224

\begin{tabular}{|l|c|c|c|c|}
$\mathbf{1}$ & Merek (X1) & 0,754 & 0,60 & Reliabel \\
\hline $\mathbf{2}$ & Kualitas Produk (X2) & 0,743 & 0,60 & Reliabel \\
\hline $\mathbf{3}$ & Harga (X3) & 0,760 & 0,60 & Reliabel \\
\hline $\mathbf{4}$ & Desain (X4) & 0,781 & 0,60 & Reliabel \\
\hline $\mathbf{5}$ & Keputusan Pembelian (Y) & 0,807 & 0,60 & Reliabel \\
\hline
\end{tabular}

Sumber: Data Primer (Diolah 2019)

Berdasarkan hasil pengujian reliabilitas pada Tabel di atas dapat diketahui bahwa semua variabel dalam penelitian ini dianggap reliabel, karena masing-masing variabel memiliki nilai Cronbach Alpha lebih besar atau sama dengan 0,60 $(a>0,60)$.

\section{Hasil Uji Regresi Linear Berganda}

Hasil analisis uji Regresi Linear Berganda dapat dilihat pada Tabel berikut ini:

Tabel 4. Hasil Analisis Regresi Linear Berganda

\begin{tabular}{|c|c|c|c|c|c|c|}
\hline \multicolumn{7}{|c|}{ Variabel Dependen : Keputusan Pembelian } \\
\hline \multicolumn{2}{|c|}{ Model } & \multicolumn{2}{|c|}{$\begin{array}{l}\text { Unstandardized } \\
\text { Coefficients }\end{array}$} & \multirow{3}{*}{$\begin{array}{c}\begin{array}{c}\text { Standardized } \\
\text { Coefficients }\end{array} \\
\text { Beta } \\
\end{array}$} & \multirow{3}{*}{$\begin{array}{c}T \\
1.161\end{array}$} & \multirow{3}{*}{$\begin{array}{l}\text { Sig. } \\
.251\end{array}$} \\
\hline & & $\mathbf{B}$ & Std. Error & & & \\
\hline \multirow{5}{*}{1} & (Constant) & .526 & .453 & & & \\
\hline & Merek (X1) & .274 & .097 & .309 & 2.815 & .007 \\
\hline & Kualitas Produk (X2) & .179 & .076 & .223 & 2.363 & .022 \\
\hline & Harga (X3) & .187 & .081 & .233 & 2.3 & .025 \\
\hline & Desain (X4) & .232 & .068 & .334 & 3.393 & .001 \\
\hline \multicolumn{2}{|c|}{ Sig F } & .000 & & & & \\
\hline \multicolumn{2}{|l|}{$\mathbf{R}$} & .751 & & & & \\
\hline \multicolumn{2}{|c|}{ R Square } & .564 & & & & \\
\hline
\end{tabular}

Sumber: Data diolah (2019)

Berdasarkan Tabel 4 di atas, dapat ditulis dalam bentuk persamaan Regresi Linear Berganda. Persamaan tersebut dapat dilihat sebagai berikut:

$$
\mathbf{Y}=0.526+0.274 \mathrm{X} 1+0.179 \mathrm{X} 2+0.187 \mathrm{X3}+0.232 \mathrm{X} 4
$$

Berdasarkan bentuk penjabaran di atas, menunjukkan bahwa variabel independen yang dianalisis yaitu variabel (X1, X2, X3, dan X4) memberi pengaruh positif terhadap variabel (Y), yaitu keputusan pembelian ban sepeda motor merek FDR di Kota Palu. Penjelasan bentuk persamaan tersebut dapat dilihat berikut ini:

Persamaan regresi tersebut dapat dijelaskan sebagai berikut:

1. Konstanta $=0.526$, menyatakan bahwa jika variabel independen (merek, kualitas produk, harga dan desain bernilai 0 atau konstan maka keputusan pembelian ban sepeda motor merek FDR di Kota Palu nilainya sebesar 0.526 .

2. Koefisien regresi $\mathrm{X} 1=0.274$, menunjukkan jika variabel merek $(\mathrm{X} 1)$ terjadi peningkatan satusatuan maka keputusan pembelian ban sepeda motor merek FDR di Kota Palu akan meningkat sebesar 0.274 .

3. Koefisien regresi $\mathrm{X} 2=0.179$, menunjukkan jika variabel kualitas produk (X2) terjadi peningkatan satu-satuan maka keputusan pembelian ban sepeda motor merek FDR di Kota Palu akan meningkat 


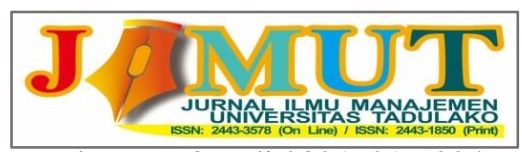

Vol. 7, No 3, Juli 2021, 216-224

sebesar 0.179 .

4. Koefisien regresi $\mathrm{X} 3=0.187$, menunjukkan jika variabel harga $(\mathrm{X} 3)$ terjadi peningkatan satusatuan maka keputusan pembelian ban sepeda motor merek FDR di Kota Palu akan meningkat sebesar 0.187 .

5. Koefisien regresi $\mathrm{X} 4=0.232$, menunjukkan jika variabel desain $(\mathrm{X} 4)$ terjadi peningkatan satusatuan maka keputusan pembelian ban sepeda motor merek FDR di Kota Palu akan meningkat sebesar 0.232 .

\section{Hasil Pengujian Hipotesis Pertama (Uji-F)}

Berdasarkan Tabel 4 di atas hasil pengujian diperoleh nilai signifikansi $F=0,00$ dan nilai signifikansi tersebut $<0,05$. Dengan demikian dapat diartikan bahwa seluruh variabel bebas meliputi merek, kualitas produk, harga dan desain secara simultan berpengaruh signifikan terhadap keputusan pembelian ban merek FDR di Kota Palu. Nilai $R$ Square dalam penelitian ini yaitu sebesar 0.564 . Hal tersebut dapat diartikan bahwa seluruh variabel bebas meliputi merek, kualitas produk, harga dan desain mempunyai kontribusi secara simultan atau bersama-sama sebesar 56,4\% terhadap variabel terikat yaitu keputusan pembelian.

\section{Hasil Pengujian Hipotesis Kedua (Uji-t)}

Hasil pengujian seperti terlihat pada pada Tabel rekapitulasi Regresi Linear Berganda di atas, menunjukkan variabel merek memiliki nilai signifikansi 0.007 , artinya nilai tersebut $<$ dari taraf signifikansi yang diisyaratkan yaitu 0.05. Hal tersebut dapat disimpulkan bahwa secara parsial merek berpengaruh signifikan terhadap keputusan pembelian ban sepeda motor merek FDR di Kota Palu dengan nilai koefisien regresi sebesar 0.309. Hal tersebut memberikan makna bahwa produk ban merek FDR mereknya yang dikenal, merek yang menggambarkan kualitas produk dan merek mudah diingat sehingga konsumen membeli ban merek FDR. Nilai rata-rata atau mean tertinggi variabel merek yaitu sebesar 4,50 dengan pernyataan indikator ketiga "ban merek FDR mudah diingat". Jadi, dapat disimpulkan bahwa jawaban responden pada indikator mudah diingat adalah sangat baik. Kemudian untuk nilai rata-rata atau mean terendah sebesar 4,00 dengan pernyataan indikator "ban merek FDR menggambarkan kualitas produk". Jadi, dapat disimpulkan bahwa tanggapan responden terhadap indikator merek menggambarkan kualitas produk adalah baik. Hasil penelitian menunjukkan bahwa semua indikator merek yang digunakan dalam penelitian ini memiliki peran penting sehingga untuk meningkatkan keputusan pembelian semua indikator tersebut harus di maksimalkan. Produsen ban merek FDR harus memperkenalkan merek agar lebih dikenal oleh konsumen sehingga keputusan pembelian ban merek FDR meningkat yaitu dengan lebih gencar mempromosikan produk-produk ban merek FDR. Hal ini agar ban merek FDR bisa terus bersaing dengan ban merek lain dari dalam negeri maupun luar negeri.

\section{Hasil Pengujian Hipotesis Ketiga (Uji-t)}

Hasil pengujian seperti terlihat pada Tabel rekapitulasi Regresi Linear Berganda di atas, menunjukkan variabel kualitas produk memiliki nilai signifikansi 0.022 , artinya nilai tersebut $<$ dari taraf signifikansi yang diisyaratkan yaitu 0.05. Hal tersebut dapat disimpulkan bahwa secara parsial kualitas produk berpengaruh signifikan terhadap keputusan pembelian ban sepeda motor merek FDR di Kota Palu dengan nilai koefisien regresi sebesar 0.223. Hal tersebut memberikan makna bahwa produk ban FDR memiliki kualitas produk yang memenuhi kebutuhan konsumen dari segi kinerja yaitu tidak mudah selip saat digunakan, dapat diandalkan, serta memiliki pola tapak ban yang menarik sehingga konsumen membeli ban merek FDR. Nilai rata-rata atau mean tertinggi pada variabel 


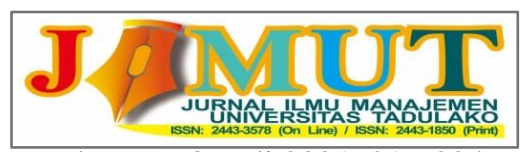

Vol. 7, No 3, Juli 2021, 216-224

kualitas produk yaitu sebesar 4,53 dengan pernyataan indikator ketiga "ban merek FDR memiliki corak yang menarik". Jadi, dapat disimpulkan bahwa jawaban responden pada indikator ini adalah sangat baik. Selanjutnya untuk nilai rata-rata atau mean terendah sebesar 4,00 dengan pernyataan indikator pertama "ban merek FDR tidak mudah selip saat digunakan". Jadi, dapat disimpulkan bahwa tanggapan responden terhadap indikator kinerja adalah baik. Hasil penelitian menunjukkan bahwa semua indikator kualitas produk yang digunakan dalam penelitian ini memiliki peran penting sehingga untuk meningkatkan keputusan pembelian semua indikator tersebut harus di maksimalkan. Produsen ban sepeda motor merek FDR harus terus melakukan inovasi terhadap produk bannya dengan memproduksi ban yang berkualitas untuk meningkatkan keputusan pembelian.

\section{Hasil Pengujian Hipotesis Keempat (Uji-t)}

Hasil pengujian seperti terlihat pada Tabel rekapitulasi Regresi Linear Berganda di atas, menunjukkan variabel harga memiliki nilai signifikansi 0.025 , artinya nilai tersebut $<$ dari taraf signifikansi yang diisyaratkan yaitu 0.05. Hal tersebut dapat disimpulkan bahwa secara parsial harga berpengaruh signifikan terhadap keputusan pembelian ban sepeda motor merek FDR di Kota Palu dengan nilai koefisien regresi sebesar 0.233 . Hal tersebut memberikan makna bahwa produk ban yang memiliki harga yang terjangkau, harga yang sesuai dengan kualitas produk serta harga yang bersaing dengan ban merek lain sehingga konsumen membeli ban merek FDR. Nilai rata-rata atau mean tertinggi variabel harga yaitu sebesar 4,60 dengan pernyataan indikator ketiga "harga ban merek FDR memiliki daya saing dengan ban merek lain". Jadi, dapat disimpulkan bahwa jawaban responden pada indikator harga bersaing dengan produk lain adalah sangat baik. Selanjutnya untuk nilai rata-rata atau mean terendah sebesar 4,02 dengan pernyataan indikator pertama "harga ban merek FDR terjangkau". Jadi, dapat disimpulkan bahwa tanggapan responden terhadap indikator harga terjangkau adalah baik. Hasil penelitian menunjukkan bahwa semua indikator harga yang digunakan dalam penelitian ini memiliki peran penting sehingga untuk meningkatkan keputusan pembelian semua indikator tersebut harus di maksimalkan. Produsen ban merek FDR harus jeli dalam menetapkan harga produknya. Suatu produk akan diminati jika harga yang ditawarkan sesuai dengan persepsi konsumen.

\section{Hasil Pengujian Hipotesis Kelima (Uji-t)}

Hasil pengujian seperti terlihat pada Tabel rekapitulasi Regresi Linear Berganda di atas, menunjukkan variabel desain memiliki nilai signifikansi 0.001 , artinya nilai tersebut $<$ dari taraf signifikansi yang diisyaratkan yaitu 0.05. Hal tersebut dapat disimpulkan bahwa secara parsial desain berpengaruh signifikan terhadap keputusan pembelian ban sepeda motor merek FDR di Kota Palu dengan nilai koefisien regresi sebesar 0.334. Hal tersebut memberikan makna bahwa dengan desain produk ban yang sesuai dengan standar dan kualitas yang ditawarkan, memiliki daya tahan yang baik serta memiliki model yang bervariasi sehingga konsumen membeli ban merek FDR. Nilai rata-rata atau mean tertinggi variabel desain yaitu sebesar 4,58 dengan pernyataan indikator ketiga "desain ban merek FDR memiliki model yang bervariasi". Jadi, dapat disimpulkan bahwa jawaban responden pada indikator ini adalah sangat baik. Selanjutnya untuk nilai rata-rata atau mean terendah sebesar 4,05 dengan pernyataan indikator pertama "ban merek FDR sesuai dengan standar dan kualitas yang ditawarkan". Jadi, dapat disimpulkan bahwa tanggapan responden terhadap indikator ini adalah baik. Hasil penelitian menunjukkan bahwa semua indikator desain yang digunakan dalam penelitian ini memiliki peran penting sehingga untuk meningkatkan keputusan pembelian semua indikator tersebut harus di maksimalkan. Semakin bagus desain suatu produk maka akan meningkatkan proses keputusan pembelian. 


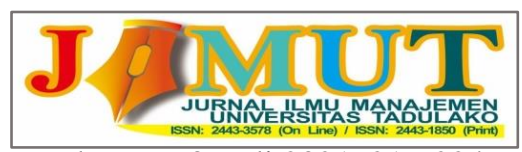

Vol. 7, No 3, Juli 2021, 216-224

\section{KESIMPULAN DAN SARAN}

Berdasarkan hasil penelitian, maka dapat diambil kesimpulan sebagai berikut:

1. Atribut produk yang terdiri dari merek, kualitas produk, harga dan desain berpengaruh signifikan terhadap keputusan pembelian ban sepeda motor merek FDR di Kota Palu.

2. Merek berpengaruh signifikan terhadap keputusan pembelian ban Sepeda motor merek FDR di Kota Palu.

3. Kualitas produk berpengaruh signifikan terhadap keputusan pembelian ban Sepeda motor merek FDR di Kota Palu.

4. Harga berpengaruh signifikan terhadap keputusan pembelian ban Sepeda motor merek FDR di Kota Palu.

5. Desain berpengaruh signifikan terhadap keputusan pembelian ban sepeda motor merek FDR di Kota Palu.

Berdasarkan hasil penelitian, maka ada beberapa saran: (1) Bagi perusahaan, variabel merek memiliki pengaruh paling dominan terhadap keputusan pembelian maka dari itu diharapkan pihak perusahaan lebih memperkenalkan ban merek FDR yaitu dengan melakukan promosi sehingga persepsi konsumen terhadap ban merek FDR semakin baik sehingga keputusan pembelian meningkat. Variabel kualitas produk memiliki pengaruh paling rendah terhadap keputusan pembelian. Pihak perusahaan ban merek FDR diharapkan bisa meningkatkan kualitas produk khususnya dari segi kinerja misalnya memproduksi ban sepeda motor dari bahan yang tidak gampang selip saat digunakan pada kondisi hujan atau basah; (2) Bagi penelitian selanjutnya, variabel bebas dalam penelitian ini berpengaruh sebesar 56,4\% sehingga masih ada 43,6 \% dipengaruhi oleh variabel lain yang tidak ada dalam penelitian ini. Sehingga untuk penelitian selanjutnya diharapkan hasil penelitian ini dijadikan acuan dalam mengembangkan penelitian yang berkaitan dengan keputusan pembelian dengan mempertimbangkan variabel lain yang tidak ada dalam penelitian ini.

\section{REFERENSI}

Kotler, P dan G. Amstrong, 2008. Prinsip-prinsip pemasaran. Jilid Satu. Erlangga, Jakarta.

Kotler, Philip dan Keller, Kevin Lane, 2009. Manajemen Pemasaran, Edisi 12, Jilid 1, PT. Indeks, Jakarta.

Peter, J. Paul dan Jerry C. Olson. (2014). Perilaku Konsumen \& Strategi pemasaran. Edisi 9 buku 2. Salembe Empat, Jakarta.

Sugiyono, 2014. Metode Penelitian Bisnis. CV. Alfabeta, Bandung.

Suryabrata, 2014. Metodologi penelitian. PT. Rata Grafindo Persada, Jakarta.

Tjiptono, Fandy, 2008. Strategi Pemasaran, Edisi ketiga. CV. ANDI OFFSET. Yogyakarta. 